\title{
In medisch-psychologisch perspectief
}

\author{
Citation for published version (APA):
}

Bremer, J. J. C. B. (1997). In medisch-psychologisch perspectief. Maastricht University. https://doi.org/10.26481/spe.19971107jb

Document status and date:

Published: 07/11/1997

DOI:

10.26481/spe.19971107jb

Document Version:

Publisher's PDF, also known as Version of record

\section{Please check the document version of this publication:}

- A submitted manuscript is the version of the article upon submission and before peer-review. There can be important differences between the submitted version and the official published version of record.

People interested in the research are advised to contact the author for the final version of the publication, or visit the DOI to the publisher's website.

- The final author version and the galley proof are versions of the publication after peer review.

- The final published version features the final layout of the paper including the volume, issue and page numbers.

Link to publication

\footnotetext{
General rights rights.

- You may freely distribute the URL identifying the publication in the public portal. please follow below link for the End User Agreement:

www.umlib.nl/taverne-license

Take down policy

If you believe that this document breaches copyright please contact us at:

repository@maastrichtuniversity.nl

providing details and we will investigate your claim.
}

Copyright and moral rights for the publications made accessible in the public portal are retained by the authors and/or other copyright owners and it is a condition of accessing publications that users recognise and abide by the legal requirements associated with these

- Users may download and print one copy of any publication from the public portal for the purpose of private study or research.

- You may not further distribute the material or use it for any profit-making activity or commercial gain

If the publication is distributed under the terms of Article $25 \mathrm{fa}$ of the Dutch Copyright Act, indicated by the "Taverne" license above, 


\section{Universiteitsbibliotheek}

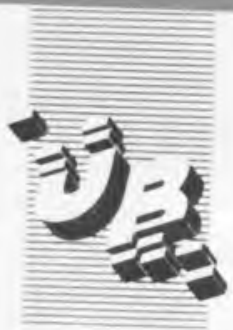

De uitleentermijn verstrijkt op:

\section{- 9 OEC, 1997}

Universiteit Maastricht Postbus 616

6200 MD Maastricht
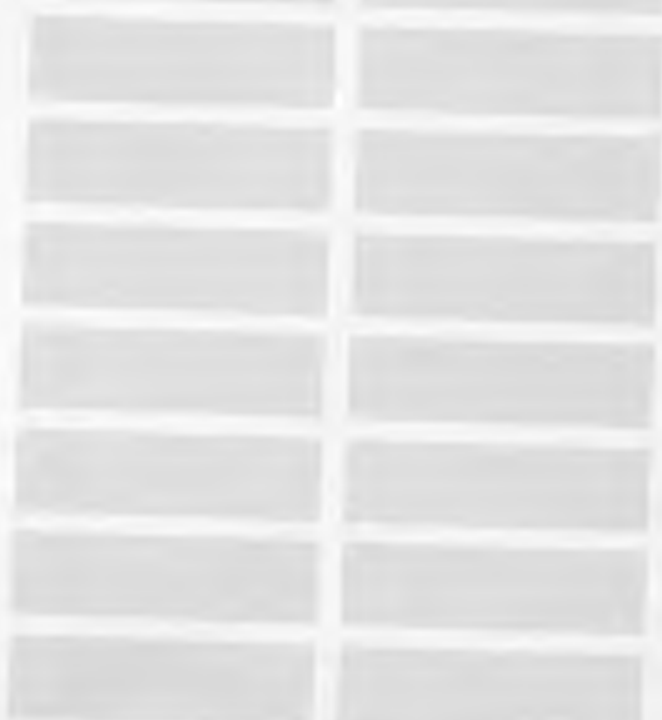

Gelieve deze publicatie tijdig te retourneren of (telefonisch) verlenging van de uitleentermijn aan te vragen.

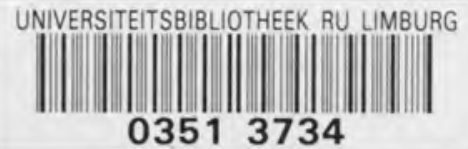


"IN MEDISCH-PSYCHOLOGISCH PERSPECTIEF"

Rede uitgesproken door

Prof. Dr. Joost J.C.B. BREMER

ter gelegenheid van zijn afscheid als hoogleraar Medische Psychologie

in de Faculteit der Geneeskunde van de Universiteit Maastricht

op vrijdag, 7 november 1997 
Mijnheer de Rector Magnificus,

Mijnheer de Decaan van de Faculteit der Geneeskunde.

Dames en heren collega's, en u allen die door uw aanwezigheid blijk geeft van uw belangstelling.

Waarde toehoorders,

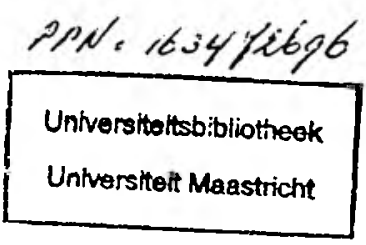

Everything passes and vanishes

Everything leaves its trace

And often you see in a footstep

What you could not see in a face

(William Allingham)

Gezien Uw aanwezigheid en mijn eerste indruk van $U$ allen neem ik aan, dat mijn gezicht $U$ vertrouwd is. Voor mijn voetsporen geldt dat zeker niet. Daarvan kent ieder van U slechts onderdelen, verspreid over diverse trajecten en perioden. De geciteerde strofe van William Allingham overnemend met name wat betreft "often you see in a footstep what you could not see in a face" wil ik $U$ aan de hand van het spoor van mijn voetstappen meer laten zien dan ik met mijn gezicht tot uitdrukking weet te brengen. Overigens hoop ik daarbij mijn voetspoor niet tot voetstuk te maken. 


\section{TER INLEIDING}

$\mathrm{U}$ kunt zich voorstellen dat bij de voorbereiding van datgene, wat ik ten afscheid van mijn ambtelijke loopbaan, wil zeggen, bij mij vele ervaringen, herinneringen en gedachten over elkaar tuimelden. Ik realiseerde mij daarbij eigenlijk pas goed dat ik reeds 45 jaar als praktiserend psycholoog werkzaam ben. $\mathrm{Na}$ mijn militaire dienst als aanstaand psycholoog in het toenmalig Militair Neurose Hospitaal te Austerlitz volgden 20 jaar als klinisch psycholoog, en wel als hoofd van de afdeling klinische psychologie aan de Ursulakliniek te Wassenaar, destijds een categoraal ziekenhuis voor wat toen heetten de drie zenuwspecialismen: psychiatrie, neurologie en neurochirurgie. Deze functie combineerde ik met opzet steeds met werk in de ambulante geestelijke gezondheidszorg om niet geheel gevangen te raken in de toen tot isolement geneigde intramurale klinische zorg. Op dit moment zal ik bij deze eerste periode van mijn professionele carrière niet lang stilstaan. Het was een buitengewoon fascinerende tijd, waarin zich op ons vakgebied vele ontwikkelingen voordeden, vooral op het gebied van assessment van psychische functies en van persoonlijkheidskenmerken. In die tijd reeds wist ik mij gesteld op een vooruitgeschoven post in de klinische psychologie. Bij de vele uitdagingen die daarvan uitgingen, heb ik mij steeds gesteund gevoeld door vele intercollegiale contacten, welke door bloeiende professionele netwerken op de gebieden van psychodiagnostiek, psychotherapie en neuropsychologie, werden gevoed.

In die periode werd vorm gegeven aan de samenwerking van medisch specialist en klinisch psycholoog in die zin dat de onderlinge verwachtingen op elkaar moesten worden afgestemd. Verantwoordelijkheden moesten worden verdeeld, competenties erkend en teamsamenwerking ontwikkeld. Dat alles naar ieders overtuiging ten behoeve van de patiënt. Hoe ervaart deze echter wat er voor hem/haar gebeurt? In welke positie ervaart de patiënt zich? Hoe beleeft hij zijn situatie in het ziekenhuis? Wat voor betekenis verleent hij aan alles om zich heen: de mensen, dokter, verpleegkundige, medepatiënt, de ruimten, de dingen, de tijd? Deze vragen vormden uitgangspunt voor een multidimensionale analyse van de belevingswereld van de ziekenhuispatiënt die de basis vormde voor mijn proefschrift.

De studie droeg bij aan kennis en inzicht betreffende de problematiek van de ziekenhuispatiënt en de aanpassing, die van hem gevergd wordt door zijn overgang van de wereld der gezonden naar die van zieken in een instituut met een heel eigen psychologisch klimaat en cultuur.

Hier volsta ik met de constatering dat het voor alle professionals rond de ziekenhuispatiënt zaak is om naast hun vakspecifieke inzet voldoende oog te hebben en te houden voor de hulp 
die patiënten nodig hebben om hun ziekte en de daarbij nodige medische ingrepen te verwerken en zich aan te passen aan de onvertrouwde ziekenhuissituatie. Een ziekenhuis dient de plaats te zijn, waar iedereen, die daarop is aangewezen, niet alleen zeker kan zijn van goede somatische zorg, maar ook van voldoende aandacht voor de psychische aspecten van zijn situatie.

Juist de aandacht voor deze psychische aspecten van ziek-zijn is richtinggevend en vraagstellingbepalend voor de medische psychologie. Dit brengt met zich mee dat de medische psychologie zich, naast ontstaan, beloop, behandeling en secundaire preventie van de psychologische complicaties van ziekte en gezondheidsverlies, bezighoudt met de wijze waarop de lijdensdruk van ziekte zich uit in gevoelens, gedachten en gedragingen. 


\section{ENTREE}

$\mathrm{Na}$ de realisatie van universitaire opleidings- en onderzoeksprogramma's en door ontwikkeling van eigen methodieken en toepassingsvormen van psychologie kwam de klinische psychologie tot ontwikkeling als eigen specialisatiegebied. Klinisch psychologen deden hun entree eerst in de psychiatrische ziekenhuizen, maar al gauw ook in de algemene ziekenhuizen. In dat kader kwam de medische psychologie als specialisatiegebied tot ontwikkeling en wel als psychologie van de patiënt in zijn medische situatie. De medische psychologie bestudeert de gedrags- en belevingsdeterminanten, die aanleiding geven tot ziekte en ziektegedrag. Voorts onderzoekt zij de mogelijkheden om afwijkende gedragsreacties op somatische ziekten te voorkomen, herkennen en te behandelen.

Psychologie ontstaat daar, waar zij nodig is. In de afgelopen decennia bleek zij als medisch psychologie steeds meer nodig op diverse werkgebieden van de geneeskunde. Aanvankelijk waren het vooral de psychiatrie, kindergeneeskunde en neurologie die de inbreng van psychologen behoefden. Geleidelijk aan werden zij op steeds meer klinische afdelingen ingeschakeld. leder nieuw werkgebied stelde de medische psychologie voor nieuwe uitdagingen waarvoor ervaring moest worden opgebouwd op basis van specifiek onderzoek. Fungeerde de medisch/klinisch psycholoog eerst vooral als psychodiagnosticus, zich baserend op empirisch testonderzoek, in de loop der jaren werd hij steeds actiever betrokken in de directe patiëntenzorg, niet alleen voor consultatie, maar ook voor begeleiding en psychotherapie, gericht op verandering van gevoelens, denkwijzen en/of gedrag.

Medische psychologie wordt nogal eens vereenzelvigd met psychosomatiek. Geïnspireerd door psychoanalytische verklaringswijzen zijn in de psychosomatiek specifieke theorieèn ontworpen over het ontstaan en voortduren van bepaalde ziektebeelden zoals de zogenaamde holy seven van Alexander: ulcus ventriculi, astma, essentiële hypertensie, colitis ulcerosa, hyperthyreoïdie, reumatoïde artritis en neurodermatitis.

De psychosomatische theorieën betreffende deze ziektebeelden heropenden de ogen voor de rol van psychische factoren bij bepaalde lichamelijke aandoeningen. Deze theorieën waren gevormd uit psychoanalytische begrippen en ideeën. De veronderstelling was dat specifieke, vooral verơrongen conflicten en complexen zouden resulteren in bepaalde persoonlijkheidskenmerken. Zo zou de astmapatiënt gekenmerkt worden door angstige afhankelijkheid en door onvermogen tot uiting geven aan negatieve emoties met name agressie en verdriet; de hypertensie-patiënt door diep verdrongen agressieve impulsen en protestvolle onderdrukking etc. 
Naast deze ziekte-kenmerkende, specifieke persoonlijkheidsprofielen werd een cruciale rol toegekend aan specifieke conflictsituaties met bepaalde sleutelfiguren. Met de componenten: specifieke persoonlijkheidskenmerken, problematiek in de vroege jeugd en actuele conflictsituaties, die de overgevoeligheid voor deze problematiek provoceren, werden zogenaamde specifiteitshypothesen gevormd.

Deze, veelal vanuit de psychiatrie gegenereerde en gepropageerde verklaringswijzen bleken geen steun te vinden in gericht empirisch medisch psychologisch onderzoek. Het waren namelijk juist overwegend psychologen, die het gemis aan steun voor deze specifiteitshypothesen aantoonden door middel van empirisch analytisch onderzoek.

Niet alleen bleek aan zgn. specifieke persoonlijkheidskenmerken geen of nauwelijks enige causale functie te kunnen worden toegekend in het ontstaan van deze, veelal chronische ziekten, maar ook de rol van negatieve emoties zoals angst, wrok, irritatie en depressiviteit bleken meer gevolg dan ourzaak, meer kenmerkend voor het omgaan met de ziekte dan voor het ontstaan daarvan (Kraaimaat, 1996).

Met de opkomst van gedragstherapie, gebaseerd op leertheorieën, kreeg de historiciteit van de mens als leergeschiedenis steeds meer aandacht. Daarmee werden nieuwe verklaringsmogelijkheden geboden voor de vorming van leefgewoonten, voor het effect van life-events en voor de invloed van daily hassles, de bij herhaling, zo niet dagelijks ervaren irritaties, frustraties en ongemakken. "De erkenning dat leefgewoonten waarschijnlijk de belangrijkste bijdrage leveren aan het ontstaan en in standhouden van ziekte", aldus Klip (1991), "is een grote uitdaging voor de medische psychologie".

Ook al behoeft deze uitspraak betreffende ziekte-etiologie de nodige nuancering, zeker is dat de vraag hoe en in welke mate leefgewoonten bijdragen aan het onderhevig raken en blijven van bepaalde ziekten nog talloze nieuwe vraagstellingen voor verder medisch psychologisch onderzoek zal opleveren. Verandering van leefgewoonten bij bepaalde chronisch zieken kan leiden tot verbetering van de kwaliteit van leven en tot meer adequaat gebruik van medische voorzieningen (Bremer Schulte e.a. 1995).

Bij het onderzoek op dit gebied sluit de veelbelovende ontwikkeling aan van diverse gedragsen cognitieve therapievormen, welke in toenemende mate ook bij bepaalde somatoforme klachten en somatoform ziektegedrag worden toegepast. Voorzover deze klachten, leefgewoonten en klachtbestendigende gedragingen zijn aangeleerd, kunnen deze in principe ook weer worden afgeleerd c.q. door aanlering van alternatieve denk- en gedragswijzen worden vervangen. Aan de ontwikkelingen op dit gebied van de zgn. behavioural medicine draagt de medische psychologie in belangrijke mate bij. 
Het entree van de psychologen in de gezondheidszorg viel samen met het steeds meer uiteengaan van de somatische en geestelijke gezondheidszorg. Zelf was ik in de praktijk van beide velden betrokken. De psychologen werkzaam in algemene ziekenhuizen bleven hun werk en afdeling veelal nog aanduiden als klinische psychologie. Mede door de instelling van leerstoelen medische psychologie aan de faculteiten geneeskunde werd de benaming medische psychologie in de academische ziekenhuizen gangbaar en aangewezen en wel als aanduiding voor die psychologie, die betrekking heeft op de belevingen, gedachten en gedragingen van mensen in medische situaties.

Het gaat dan over de psychologische factoren die een rol spelen bij het ontstaan en instandhouden van reacties op ziekte dan wel de genezing daarvan bevorderen of juist in de weg staan. Daarbij zijn ook aspecten van geestelijke gezondheid in het geding, met name wanneer de draaglast van de ziekte de draagkracht van de patiënt te boven gaat.

Juist in de consultatieve medische psychologie is vaak het tussengebied tussen somatische en geestelijke gezondheidszorg aan de orde. Voor een deel is medische psychologie geestelijke gezondheidszorg van mensen met lichamelijke klachten.

\section{START}

In het begin van de zeventiger jaren had de Commissie van Voorbereiding onder leiding van wijlen Dr. J. Tans de Basisfilosofie Achtste Medische Faculteit (1972) opgesteld, "bedoeld om kandidaten te interesseren voor de functie in de kerngroep van hoogleraren en lectoren, die het curriculum moesten voorbereiden" (Knegtmans, 1992). In die basisfilosofie was uitdrukkelijk een belangrijke plaats voor de gedragswetenschappen in het curriculum geneeskunde opgenomen. Toen mij de mogelijkheid werd geboden om daarvan de medische psychologie te gaan behartigen heb ik daar met mijn vrouw overtuigd voor gekozen. Met de eerste 12 hoogleraren en diverse medewerkers begonnen wij toen het grote avontuur van de start van een op vernieuwing van het medisch onderwijs gerichte faculteit.

Intussen waren wij met deze eerste ploeg ons uitgebreid gaan oriënteren over het probleem georiënteerde onderwijs. Eenmaal in Maastricht, het was juli 1974, vormde het Psychomedisch Streekcentrum Vijverdal mijn eerste werkplek. Daar begon het voetspoor van de huidige vakgroep Medische Psychologie.

Ik zal nooit vergeten hoe ik daar belandde in een kamer met alleen vloerbedekking en op de grond een telefoontoestel aan zijn draadje uit de muur, geen medewerker, geen stoel, geen 
bureau, geen boek zelfs. Wel veel uitdaging, veel plannen, veel enthousiasme en veel onderlinge synergie!

Een capaciteitsgroep moest worden gevormd. Contacten met gezondheidsinstellingen, waaronder het ziekenhuis, werden gelegd en onderwijs en onderzoek ontwikkeld. Behalve de genoemde basisfilosotie was er vooraf geen specifiek structuurrapport Medische Psychologie, maar ik had dat ter benoeming zelf kunnen opstellen. Dat behoorde bij de voordelen van het van voorafaan beginnen. Tot de lang nawerkende nadelen behoorde dat de capaciteitsgroep ver van het ziekenhuis was gehuisvest. Een schrale troost was dat dit extramurale lot niet alleen de vakgroep Medische Psychologie trof. Een feit is dat hierdoor het samengaan van vakgroep en ziekenhuisafdeling niet is bevorderd. Eerst na vele omzwervingen langs diverse locaties is de vakgroep Medische Psychologie thans in de nieuwbouw annex aan de desbetreffende afdeling van het Academisch Ziekenhuis Maastricht functioneel goed gehuisvest.

De eerste taak voor de vakgroep was vorm te geven aan de onderwijsinbreng op het gebied van de medische psychologie en bij te dragen aan de ontwikkeling van het onderwijs in het algemeen. Het probleemgeoriënteerde onderwijssysteem vroeg om een matrix-structuur, waarin themata centraal staan en de voor ieder thema relevante vakgroepen hun bijdragen leveren in de vorm van casus, literatuur, colleges, toetsvragen e.d. Vanuit een inschatting betreffende de gewenste dan wel verwachte bijdrage van medische psychologie aan de diverse thema's heb ik de vakgroep nogal heterogeen samengesteld, zodat daarin naast klinische psychologie, o.a. psychofysiologie, psychogerontologie, cultuurpsychologie en ontwikkelingspsychologie aanwezig zouden zijn. Deze veelzijdigheid in kwaliteiten en deskundigheden kwam het onderwijs zeer ten goede. Minder bevorderend was deze heterogeniteit voor integratie van vakgroep en ziekenhuisafdeling, waarover straks meer. Onderwijs stond dus op de eerste plaats. Niet alleen toen maar ook nu gaat onderwijs altijd voor. Overigens niet verbazend.

De primaire taak van een universiteit is immers altijd het geven van onderwijs geweest. Op minstens gelijke hoogte in waardenhiërarchie komt overigens de bron van kennis: het wetenschappelijk onderzoek. Als vrijwel de enige van alle Europese instellingen die wij kennen, heeft iedere universiteit een ononderbroken geschiedenis van continuïteit van onderwijs. Iedere opsomming van taken hetzij van universiteit, hetzij van faculteit of vakgroep pleegt terecht te beginnen met onderwijs.

De kernstaf van universiteiten bestaat uit hoogléraren. Hun functie is en blijft die van houder van een lérstoel ook al betreft het een top-onderzoeker of top-referente klinicus. Structuur- 
rapporten beginnen dan ook na de omschrijving van de leerstoel, vrijwel steeds met de paragraaf onderwijs. Een hoogleraar blijft op de eerste plaats een leraar.

Zes eeuwen na het ontstaan van de eerste universiteit bracht Wilhelm van Humboldt aan het begin van de 19 e eeuw de universiteit van Berlijn tot stand. Ook al verbond hij naast de onderwijstaak ook de verplichting tot creatief onderzoek, voorop bleef, naast scholing, als primaire doelstelling de vorming van studenten.

Deze Bildung diende de student zich te verwerven door in voortdurende zelfwerkzaamheid gebruik te maken van alle mogelijkheden die de universiteit daartoe te bieden had. Docenten hadden studenten daarin te begeleiden d.w.z. de weg te wijzen, zij waren er niet om hen te beleren en te indoctrineren, maar om als neo-socratici in discussie met studenten deze de richting aan te geven naar kritische wetenschaps- en beroepsbeoefening.

Ook in ons probleem-georiënteerde onderwijssysteem, zijn Humboldt's 19-eeuwse richtlijnen voor zelfwerkzaamheid voor studenten en neo-socratische attitude voor docenten nog steeds actueel.

In zijn oratie onderscheidde A. Wintzen (1996) tweeërlei opvattingen bij docenten over onderwijs: zij die zichzelf zien als boetseerders (bij W. "kleiers") en zij die zich zien als beeldhouwers.

Voor boetseerders bestaat onderwijs uit het toevoegen van kennis aan de student uit de voorraad van de docent zoals men een beeld van klei maakt door er net zo lang stukjes klei aan te plakken tot het gewenste model verkregen is.

Beeldhouwers menen dat het beeld al in het marmer aanwezig is en dat er juist iets moet worden verwijderd om het te zien te krijgen. Ter verduidelijking van de beeldhouwersvariant voegde Wintzen daaraan toe: 'Het beroemde beeld "De Denker" van Rodin zat al miljoenen jaren te peinzen in een marmergroeve totdat deze tijdgenoot van Charcot en Duchenne het meesterwerk van het overtollige marmer ontdeed'.

In het probleemgestuurd onderwijs zijn beide genoemde varianten terug te vinden. De beeldhouwvisie typeert de rol van de tutor in de brainstorm-fase waarin het betreffende probleem wordt gedefinieerd en de verklaringswijzen systematisch worden geïnventariseerd. $\mathrm{Na}$ formulering van de leerdoelen krijgt in de fase van informatieverzameling het boetseermodel de overhand. Het raadplegen van literatuur en van inhoudsdeskundigen, inclusief colleges, zorgt voor de toevoeging van kennisonderdelen, welke zoals bij boetseren aangebracht op de juiste plaats en in de juiste proporties in de relevante context het beeld dat de student zich vormt van de realiteit steeds beter gelijkend behoort te maken. 
Overigens zal dit beeld nooit de totale realiteit weergeven, evenmin als het beeld dat de wetenschap van de realiteit tracht te bemeten. Zoals mijn vader, tevens mijn natuurkundeleraar, placht te benadrukken: "Meten is benaderen!" zo zal het beeld dat de student zich van de mens als object van de geneeskunde vormt steeds een onvoltooide benadering blijven. Bij het memoreren van mijn vader veroorloof $\mathrm{ik}$ mij een terzijde.

\section{TERZIJDE}

Op het eind van zijn conrectoraat van het Bonifatius Lyceum te Utrecht, promoveerde mijn vader op het onderwerp: "Wijsgerige aspecten van het natuurkundig tijdbegrip". In dat kader correspondeerde hij met Albert Einstein. Deze schreef hem én jaar voor zijn dood een brief, waarin hij inging op de reden, dat de Leidse Lorentz de relativiteitstheorie tot vlakbij benaderde, maar net niet ontdekte. Zijn beschrijving van diens benadering besluit hij met de woorden: "Dass er diesem letzten Schritt zur speziellen Relativitätstheorie nicht machte lag einfach darin. dass es für Ihn psychologisch unmöglich war, auf die Realităı des Aethers als eines materiellen Dinges zu verzichten:" Daaraan voegde hij als laatste zin van deze brief toe: "Wer diese Zeit miterlebt hat, begreift es!" Om twee redenen vermeld ik hier deze, niet alleen voor onze familie, zo historische brief van Einstein. Ten eerste vanwege de psychologische verklaring, die de nobelgeprezen fysicus Einstein hier geeft: Lorenz miste de persoonlijkheidsstructuur, was te rigide om de aethertheorie betreffende het licht als beweging los te laten. Ten tweede vanwege de door Einstein getoonde empathie voor het tijdsgebonden begrijpen van gebeurtenissen: "Wer diese Zeit miterlebt hat, begreift es!" Deze laatste uitroep herhaal ik hier maar al te graag om begrip te wekken voor de snelle opeenvolging van de verschillende theorieën en praktijken, die in de loop van mijn carrière opgeld deden in de psychologie. Het waren hele ommezwaaien in denken en in handelen om van fenomenologisch psycholoog, via het psychoanalytisch referentiekader vervolgens clientcentered te werk te gaan om ten slotte via het leertheoretisch paradigma gedragstherapeutisch georiënteerd te raken. Wie ieder van deze tijdperken heeft meebeleefd, die zal er begrip voor hebben. Ik zie deze ontwikkeling in de medische psychologie niet als een rechtlijnige maar veeleer als een spiraal, waarin volgens de wet van het behoud van het waardevolle ook in de nieuwe winding de zinvolle en bruikbare elementen van het voorafgaande behouden blijven. 
$\mathrm{Na}$ dit terzijde kom ik terug op de constatering, dat het beeld dat de student zich vormt van de mens als object van de geneeskunde steeds een benadering zal blijven. Hopelijk komt hij mede door de medische psychologie de individuele patiënt in de praktijk voldoende nabij ondanks behoud van de nodige professionele distantie. Gegeven Rümke's typering van de medische attitude als: maximale toenadering met behoud van distantie, vormt doorgaans de toenadering tot de patiënt voor de medisch student een grotere opgave dan het behoud van de nodige afstand. Dit ondanks het feit dat het beeld van de ideale arts bij studenten meer care-kenmerken dan cure-karakteristieken blijkt te vertonen (Batenburg, 1995). De afstand tussen het ideale ik en het actuele zelfbeeld bestaat niet alleen op persoonlijkheidsniveau maar heeft ook zijn pendant in de afstand tussen het professionele ideaalbeeld en het actuele beeld van de a.s. arts over zichzelf. In de loop van zijn opleiding heeft iedere medisch student zijn ideaalbeeld af te stemmen op de werkelijkheid van de medische hulpverlening. In het praktisch medisch onderwijs doen zich belangrijke aanpassingsopgaven in deze voor. Toenadering en bewaren van afstand moeten steeds weer in balans gebracht worden. Daarbij werken cognities, emoties en handelingsgewoonten, afhankelijk van de situatie, (te) vaak niet in dezelfde richting.

Te grote emotionele betrokkenheid vanwege overmatige empathie bemoeilijkt bijvoorbeeld het goed doen van pijnlijke onderzoeken en ingrepen; ook kan deze betrokkenheid een zakelijke medische beoordeling van patiënt en diens situatie (ver)hinderen.

Te veel distantie, bijvoorbeeld door vooringenomenheid zoals op grond van uiterlijk of van onhebbelijk gedrag, hindert bij hulpverlening door gebrek aan de nodige empathie. Afgezien van training in communicatieve vaardigheden ten behoeve van anamnestisch onderzoek en consultverlening is de bijdrage van Medische Psychologie in het practisch medisch onderwijs erop gericht de balans tussen toenadering en distantie in evenwicht te brengen door onderlinge afstemming van de gedragscomponenten van het hulpverlenend handelen. Een zekere mate van overlearning van toenadering en empathie is daarbij naar mijn ervaring aangewezen om voldoende bestand te zijn tegen intramurale klimaat van de klinische praktijk. Spreekkamerinrichting, instrumentarium, apparatuur en andere medische technologie zijn toch al meer distantie- dan toenadering-bevorderend. 


\section{PROBLEEMGEORIENTEERD ONDERWIJS}

Hoewel nooit systematisch geïnventariseerd, is er op grond van intercollegiale contacten voldoende reden om aan te nemen dat het onderwijs in de medische psychologie aan de diverse faculteiten zowel naar vorm, omvang als inhoud vele verschillen vertoont. Over de doelstelling van dat onderwijs bestaat over het algemeen de nodige consensus. Het gaat om psychologie voor zover deze voor de (a.s.) arts van betekenis is.

In het probleemgeoriënteerde onderwijs dienen de casuistiek en overige problemen als uitgangspunten voor leerdoelstellingen zo te zijn opgesteld, dat daar vooral ook bij wordt betrokken de wijze waarop de patiënt zich gedraagt, denkt en voelt.

Zo dient de belangstelling van de student voor nodige basiskennis van de psychologie te worden gestimuleerd. Kennis en inzicht in de psychologische basisbegrippen, werkingsmechanismen en verklaringen blijven steriele stof voor toetsen als deze niet worden toegepast in relevante medische sectoren. Dan gaat het over verbanden tussen lichamelijk functioneren, gedrag en beleving.

Hoe worden symptomen beleefd en wat veranderen deze aan de beleving van het eigen lichaam? Wat verandert er door de klachten en eventuele beperkingen in het dagelijks functioneren van de patiënt? Klachten als vermoeidheid, pijn, maar ook gevoelens van algemene malaise en depressiviteit kleuren ieder op hun wijze het decor, de coulissen van het dagelijks leven van de betrokkene.

Gegeven de interactie tussen gedrag, emoties, cognities en lichamelijk functioneren dient de rol van deze factoren zowel bij preventie als onderzoek en behandeling aan de orde te komen. Daarbij zal het bij gedrag dienen te gaan over leefgewoonten, bij emoties en cognities over de leergeschiedenis. Bij lichamelijk functioneren kan het gaan over de rol van psychische factoren in het ontstaan en de bestendiging van klachten, maar evenzeer om de mogelijkheden tot beïnvloeding van somatoforme klachten door gedragsverandering. De zelfcontrole, die bijvoorbeeld relaxatietraining biedt in geval van stressreacties, blijkt vaak de nodige winst aan gezondheid op te leveren. Wat betreft gedragsbeïnvloeding op het gebied van leefgewoonten behoren de mogelijkheden en beperkingen daarvan aan de orde te komen. Het grootste deel van de gezondheid en van de levensduur is afhankelijk van dagelijkse activiteiten zoals tijdig en matig eten, lichaamsbeweging, niet roken, vrijwel geen tot hooguit matig alcolholgebruik en voldoende slaap. Hoe meer van deze gezonde leefwijzen worden gevolgd, hoe hoger de leeftijdsverwachting. Vandaar dat deze in vele doktersadviezen worden verwerkt. 
De grote mate van therapie-ontrouw m.a.w. het gebrek aan compliance ten aanzien doktersadviezen en -voorschriften vormt een van de onderschatte fenomenen in de geneeskunde. In grote mate van frequentie doet zich het paradoxale feit voor dat patiënten medische hulp zoeken maar dat zij de geboden hulp veelal niet opvolgen, althans niet volledig. De grootte als ook de ernst van het incompliance-probleem onderstreept het belang van goede communicatie tussen patiënt en arts. Daarbij komt dat actieve participatie van patiènten in hun eigen behandeling een steeds grotere rol heeft te spelen met name in geval van chronische kwalen (Bremer, 1980). Constateringen als deze onderstrepen het belang van de medische psychologie in de opleiding Geneeskunde.

Mijn komst destijds naar de toenmalige Medische Faculteit Maastricht was in belangrijke mate bepaald door de onderwijsvernieuwende opzet van deze faculteit. Op grond van haar basisfilosofie werd aan de gedragswetenschappen een grotere en meer expliciete rol toegekend dan bij de overige bestaande Medische Faculteiten. Dit kwam o.a. tot uitdrukking in de geopende mogelijkheid om de medische psychologie in het gehele curriculum tot aan het basisartsexamen te betrekken en niet alleen als basisvak aan het begin van de studie geneeskunde zoals toen aan de zusterfaculteiten gebruikelijk.

Er is in de loop van mijn tijd aan deze faculteit het nodige te wensen overgebleven, wat betreft deze implementatie van de medische psychologie in het gehele curriculum Geneeskunde. Welk vak is overigens geheel voldaan in dit opzicht? Toch valt in de ruimte voor de medische psychologie in de, voor ons evaluatiesysteem zo essentiële, voortgangstoetsen het continue belang van de medische psychologie voor de opleiding tor basisarts te herkennen. In deze voortgangstoetsen worden de eindtermen geoperationaliseerd waaraan de basisarts na zijn studie geneeskunde moet voldoen. Met deze toetsen wordt iedere medisch student vanaf diens studiebegin $4 \mathrm{x}$ per jaar geëvalueerd op eindniveau over het totaal van de geneeskunde. Voordelen van deze vorm van studie-evaluatie zijn o.a. dat toetsgericht studeren vrijwel niet mogelijk is, dat alle kennisonderdelen van de studie steeds weer opnieuw aan bod (kunnen) komen en dat de student een naar vakken en onderwerpen gedifferentieerde beoordeling en direkte feedback ontvangt op de voortgang van zijn opleiding. Uit analyse van voortgangstoetsgegevens over de periode van september 1987 tot mei 1997 blijkt overigens, dat de leergroeicurve voor medische psychologie over de studiejaren 1 tot en met 6 eenzelfde curvoliniaire toename vertoont als de basisvakken in het algemeen. Deze groeicurve vlakt af in het $5 e$ en $6 \mathrm{e}$ jaar d.w.z. in de periode van het practisch medisch onderwijs. Dit blijkt bij vergelijking zowel te gelden voor de opleiding geneeskunde te Maastricht als die te Nijmegen. Tussen deze beide opleidingen bestaat het verschil, dat de medische psycholo- 
gisch kennis in Maastricht meer van meet af aan in de opleiding blijkt te zijn geïntegreerd dan in Nijmegen. Wat betreft de medische psychologie lijken de Maastrichtse studenten nog meer dan de Nijmeegse maximaal op de klinische stages te worden voorbereid, waarna de stages weinig meer aan hun psychologisch kennis lijken toe te voegen.

Het is overigens verheugend, dat voor de keuzestage medische psychologie bij de afdeling van het ziekenhuis twee maal meer belangstelling bestaat dan kan worden gerealiseerd.

De mate van doorwerking van het onderwijs in de medische psychologie hangt af van de wijze, waarop de voor de medische student relevante theoretische stof wordt herkend. Dit is ten eerste in het aanbod van de patiëntproblemen, zoals die in het probleemgestuurd predoctorale onderwijs worden geboden. Ten tweede, wellicht in veel belangrijker mate, in wat hij daarvan in de praktijk van zijn praktisch medische stages terugvindt.

In de predoctorale fase kunnen de multidisciplinair samengestelde planningsgroepen voor de nodige evenwichtigheid in het aanbod van problemen en literatuur zorgen.

In de stages ter beroepsopleiding speelt het model-leren een grote rol. De voornaamste modellen waarmee hij zich in die beslissende perioden identificeert zijn de voor hem belangrijke specialisten en assistenten. Hoe meer deze zelf oog en oor hebben voor de psychische problematiek van hun patiënten, hoe meer diegenen, die zij superviseren dit zullen overnemen. Dat deze identificatie-figuren in de praktijk zelf het belang demonstreren van psychologische bevindingen en inzichten is van grote betekenis.

In de fase van de praktisch medische stages zouden de onderzoeks- of consultaanvragen voor de medische psychologie meer in het algemeen behandeld kunnen worden in patiëntgebonden besprekingen. Dit om meer begrip te krijgen zowel voor de vragen als voor de antwoorden rond de desbetreffende aanvragen. Daarbij dienen de geconsulteerde psychologen zich te realiseren, dat consultatie meer is gediend met overleg en toelichting dan met schriftelijke rapportage alleen. Overigens biedt het stage-overschrijdend onderwijs wellicht de nodige nieuwe mogelijkheden voor medisch-psychologisch onderwijs in de kliniek. Uiteindelijk zal de medische psychologie vooral ook zelf haar bevindingen en inzichten meer toepasbaar dienen te maken voor de medische praktijk. Wat dat betreft ligt de bewijslast bij de medische psychologie, ook al worden daar soms hogere eisen aan gesteld dan aan allerlei in de gangbare geneeskunde gepraktiseerde gewoonten. De van beide, medische en psychologische, zijden beoogde kwaliteit van de gezondheidszorg kan daar alleen maar door gediend zijn.

Nog steeds is zeker voor de opleiding tot basisarts Ruskin's adagium zeer relevant: "Education is not for knowing more but for behaving differently". 
De kennis van de medische psychologie en het inzicht daarin waarover een basisarts geacht wordt te beschikken, dienen door de vakgroep te worden aangereikt in de diverse vormen van onderwijs. Na de nodige herzieningen van het curriculum geneeskunde is de medische psychologie nu metterdaad in ieder van de vier predoctorale jaren in een of meer blokplanningsgroepen betrokken, d.w.z. in meer dan een derde van alle thematische blokken van jaar $1 \mathrm{t} / \mathrm{m}$ 4. Naast kennis en inzicht bestaat de bijdrage van medische psychologie uit het faciliteren van het aanleren van vooral communicatieve vaardigheden $0 . a$. door nabespreking van simulatiepatiëntcontacten alsook uit het leren reflecteren op eigen functioneren als vorm van attitude-ontwikkeling. Tegenwoordig gebruikt men daarvoor wel de term reflexief practicum. De vakgroep Medische Psychologie vervult in dit medisch praktisch onderwijs jaarlijks in tientallen groepen de begeleidersfunctie gedurende het hele jaar.

Het geeft voldoening dat uit recent promotie-onderzoek van Albert Scherpbier (1997), hoofd van ons Skillslab, blijkt dat verwerving van communicatieve vaardigheden door medisch studenten ter voorbereiding op de co-assistentfase van hun basisartsopleiding resulteen in hoge tevredenheidswaardering, namelijk op de tweede plaats van de zeventien onderzochte vaardigheidstrainingen.

Deze bevinding onderstreept het belang van de continue inzet van onze vakgroep Medische Psychologie in het medisch praktisch onderwijs in de eerste vier studiejaren. De bijdrage van Medische Psychologie in deze is des te meer van waarde, waar steeds weer blijkt hoe vaak en hoe indringend tekorten in communicatie en bejegening in de arts-patiënt-relatie de bron vormen voor problemen en klachten in de gezondheidszorg. Omgekeerd mag verondersteld worden, dat goede verhoudingen tussen patiënten en artsen in contactueel en communicatief opzicht de beste garantie bieden voor de nodige samenwerking tussen arts en patiënt. Deze coöperatie, hetzij actief hetzij passief, is onmisbaar voor goede geneeskundige zorg. Een doelmatige verhouding tussen arts en patiënt is voorts een waarborg tegen tijds- en energieverslindende conflicten en teleurstellingen zowel bij patiënten als. artsen.

Vanaf de start van de opleiding geneeskunde alhier vormde attitude-ontwikkeling een van de specifieke uitgangspunten en kenmerken van ons medisch onderwijssysteem. Toch is aan attitude-ontwikkeling in verhouding tot de andere specifieke uitgangspunten: probleemoriëntatie, zelfwerkzaamheid en werken in groepen, geen evenredige aandacht en energie besteed. Bovendien is het de vraag of klinici zich voldoende realiseren hoe zij voor studenten en co-assistenten fungeren als model, waarmee deze zich in het gunstige geval ten positieve identificeren en waartegen deze in het ongunstige geval zich verzetten. Soms doemde wel eens het beeld op van een in de predoctorale periode opgebouwd zandkasteel dat 
onder de vloed van de kliniek deels dreigde te worden weggespoeld. Dit ondanks het feit dat co-assistenten bij herhaling aangeven, dat zij hopen niet onderhevig te zullen worden aan bepaalde beroepsdeformerende aspecten van het klinisch bedrijf. Wat dat betreft pleit ik bij dit afscheid overtuigd voor bestendiging van deze onderwijsactiviteit, ook al dient deze nog al eens te worden gerealiseerd tegen de weerstand in van met name die studenten die deze attitude-ontwikkeling, gericht op het reflecteren op eigen functioneren, juist het meest nodig hebben. Het motto dat vanaf de start aan deze attitude-ontwikkeling, is meegegeven: 'Als je weet wat je doet, kun je beter doen wat je wilt', is mijns inziens nog steeds geldig en richtinggevend in deze.

Afgezien van alle onderwijskundige argumenten ten voordele van probleemgeoriënteerd onderwijs is een belangrijk pré in medisch psychologisch perspectief dat bij aanbod van integrale patiënt-problemen de patiënt niet bij voorbaat gereduceerd wordt tot een verstoord, ontregeld orgaansysteem. De vroegere opbouw van het traditioneel medisch onderwijs hield het risico in dat de blikrichting van de student werd vernauwd door via biomedische filters primair te focussen op het organisch substraat van de mens.

Voor de melodie van de geneeskunde, die de student dient te leren spelen met zichzelf als voornaamste instrument, stond als het ware een biomedische vioolsleutel. Ook al werd deze vioolsleutel in de daarop volgende klinische periode van zijn opleiding bijgesteld, toch bleef het risico dat hij de patiënt primair bleef zien als wel of niet, meer of minder somatisch gestoord en met als opgave het juiste etiquet van de diagnose te achterhalen. In de medische opleiding wordt de a.s. arts steeds weer geconfronteerd met pathologie, met stoornissen, afwijkingen, met buiten de norm vallende uitslagen en abnormale beelden. In het kader daarvan is het medisch handelen te zien als een activiteit die primair gericht is op het opheffen van de storing en op het terugbrengen tot de norm.

Als er één lijn in alle vernieuwingen in het medisch onderwijs is aan te wijzen, dan is dat de tendens om de grenzen tussen preklinisch en klinisch onderwijs zoveel mogelijk te slechten en van meet af aan de persoon van de patiënt als subject in balans te brengen met de wijze waarop diens lichamelijke conditie tot object van geneeskundig onderzoek moet worden gemaakt.

Probleemgestuurd onderwijs biedt de kans om patiëntenproblemen in hun levensechte context te presenteren en vervreemding van psychosociale problematiek van ziekte, handicaps of beperkingen te voorkomen.

Overigens ook al biedt probleemgeoriënteerd onderwijs meer mogelijkheden tot integrale benadering van patiëntproblemen, het risico van biomedische reductie van de patiënt tot een 
ontregeld orgaansysteem wordt er niet gegarandeerd door bezworen.

Vaak frappeert mij hoe in onderwijsgroepen in de fase van probleemstelling en

brainstorming als het ware direct onder de huid wordt gedoken tot op microniveau. Maar al te gauw wordt dan de patiënt uit het oog verloren als, ook aan zijn ziekte, betekenis verlenend persoon, levend in zijn, met intermenselijke relaties, gestructureerde omgeving.

Daar waar de specifieke medische psychologische problemen rond bepaaide hetzij acure hetzij vooral ook chronische ziektebeelden in de aangeboden patiëntproblemen worden opgenomen, wordt de belangstelling en benieuwdheid van de studenten daarvoor gewekt. En benieuwdheid blijft hopelijk, ondanks tempobeurs en studiepunten, nog steeds de tijger in de studietank. Juist voor het aanreiken van deze medische psychologische problemen dient geput te worden uit de vraagstelling en bevindingen van desbetreffend onderzoek.

Het interacademiaal afscheidssymposium "Doen en laten in de Medische Psychologie" voorzag vandaag in een aantal presentaties van recente bevindingen en inzichten op diverse deelgebieden van de medische psychologie. 


\section{PSYCHISCHE FACTOREN EN BELOOP VAN ZIEKTE}

Dat psychische factoren van invloed zijn op ontstaan, beloop en herstel van vele ziekten, hetzij primair hetzij secundair, is langzamerhand genoegzaam bekend. Toch blijven de mogelijkheden van psychologische interventies op cognitief-, emotioneel- en gedragsniveau nog al te vaak onvoldoende gebruikt. Hoewel wij weten hoezeer autonomie, zelfcontrole, sociale ondersteuning, zingeving en continuïteit van zorg van invloed zijn ook op het lichamelijk functioneren en het vermogen tot herstel van ziekte, wordt van de preventieve en therapeutische mogelijkheden van deze herstelbronnen niet in die mate gebruik gemaakt als waarin de daarvoor in aanmerking komende patiënten daarvan profijt zouden kunnen hebben. In de consultatieve hulpverlening aan ziekenhuispatiënten blijkt maar al te vaak, dat behoeften aan die ingrediënten voor herstel vaak eerst worden vervuld nadat zij van de kant van de medische psychologie zijn gesignaleerd.

Vrijwel alle lichamelijke aandoenigen hebben psychische implicaties, die de lijdensdruk extra kunnen verergeren (Bierkens, 1994). Soms spelen psychische factoren een luxerende rol, dan weer zijn zij meer gevolg van de aandoening. Waar de patiënt zich dan ook bevindt op het continuüm tussen deze beide uitersten, de psychische impact van zijn subjectief lijden wordt er niet minder op. In welk orgaansysteem ziekte ook blijkt te kunnen worden gelocaliseerd, ernstige ziekte komt ook tussen de oren terecht en ook die complicatie behoeft de nodige aandacht ter cognitieve herstructurering in geval van irrationele gedachten en misvattingen van de patiënt over zichzelf en/of over zijn ziekte.

Als toegepaste klinische discipline biedt de medische psychologie in de praktijk interpretaties van menselijk gedrag relevant voor de diagnostiek en behandeling van patiënten.

Zoals iedere wetenschap is ook de medische psychologie onderhevig aan wat Kuhn (1970) benoemd heeft als paradigma-wisselingen. Met de paradigma-verschuivingen welke in de loop der laatste decennia plaatsvonden in de medische psychologie, verschoof ook de wijze van interpreteren en verklaren van individuele patiëntenproblematiek en daarmee de wijze van (mede)behandeling en psychologische begeleiding van patiënten. Als voornaamste paradigma-verschuiving in de medisch psychologische verklaring van ziektefenomenen sinds de entree van medische psychologen in de gezondheidszorg valt aan te merken die van de psychoanalytische theorie met de daarvan afgeleide psychoanalytische therapieën naar die van de leertheorie waarop de diverse vormen van gedragstherapie zijn geënt.

Ook in de medische psychologie is er net als in de psychotherapie een toenemende tendens zich te oriënteren op pragmatische hulpverlening, evidence-based, d.w.z. gericht op 
empirisch aantoonbare effectiviteit en efficiency.

Steeds luider klinkt de roep om evidence-based medicine. Ook voor de medische psychologie vormt dit een uitdaging. De discussie uit de zestiger jaren over clinical versus statistical prediction, die toen vooral betrekking had op de psychodiagnostiek, herhaalt zich heden ten dage in die over clinical versus evidence-based indicatiestelling voor (psycho)therapie. De vraag rijst hier wat te verstaan onder evidence. Uit mijn eigen opleiding in de fenomenologische Utrechtse school met leermeesters zoals Buytendijk, Rümke, Langeveld en Van Lennep. herinner ik mij maar al te goed, dat als voornaamste legitimatie van de fenomenologische analyses de evidentie daarvan gold. De mate waarin de fenomenologische beschrijvingen van menselijke fenomenen door klaarblijkelijkheid werden gedeeld door hen die daarvan kennis namen, werd geacht de basis te vormen voor de geldigheid daarvan. Hoe anders wordt thans evidentie opgevat namelijk als empirisch aantoonbare significante voorsprong bij effect-studies van de ene behandeling of interventie boven de andere. Meer dan voorheen speelt kansberekening een rol bij zowel de interpretatie van onderzoeksbevindingen bij patiënten als bij de opstelling van behandelingsplannen. Het is dan ook niet verwonderlijk dat de besliskunde in de geneeskunde steeds meer de spelregels gat bepalen voor het medisch handelen. Ook de medische psychologie zal hiermee in toenemende mate hebben rekening te houden wil zij in de samenwerking met artsen en andere disciplines in de gezondheidszorg voldoende legitimatie behouden en in toenemende mate verwerven.

Voor de kwalitatieve beschrijving van gedragsfenomenen zal de evidentie-opvatting van de fenomenologie van waarde blijven. In ieder geval heb ik daaruit overgehouden en gehanteerd bij opposities bij promoties, dat bij experimenteel onderzoek een consciëntieuze fenomenologische descriptie en analyse van de betreffende fenomenen of gedragsvariabelen niet alleen niet mag ontbreken, maar aan het betreffende onderzoek ten grondslag moet liggen. Zonder deze dreigt immers verkokering van het zicht op de relevante samenhangen, welke experimenteel worden geanalyseerd, dreigt het gevaar van premature toepassing van algemene principes ter verklaring van de kwantitatieve onderzoeksbevindingen en loopt men het risico van beperking van de mogelijkheden tot adequate theorievorming betreffende menselijk gedrag. Op medisch psychologisch gebied gaat het daarbij vooral om ziektegedrag. Zeker in een tijd waarin gedragswetenschappers vragenlijstwetenschappers dreigen te worden, blijven klinische observaties onmisbaar evenals het luisteren naar de belevingen van patiënten, die immers tot het wezen van zijn ziek-zijn behoren. Bij dit beluisteren kan men zich nauwelijks genoeg realiseren dat wij met de patiënt spreken, spelend over de band van zijn wereld. Juist in geval van ziekte gaat zijn lichaam of klachtbezorgende delen daarvan 
meer tot zijn buitenwereld behoren: van het lichaam dat hij is en dat hij ongeweten depasseert naar de intenties van zijn handelingen, wordt dit door ziekte of gebrek een lichaam dat hij héft met hinderlijkheden, die tot klachten en hulpvragen leiden. In de beschrijving van zijn externe situatie geeft hij veel weer van zijn interne conditie. Als hij bijvoorbeeld klaagt over het lawaai en de onrust op de afdeling, waar hij verblijft spreekt hij indirect, maar niet minder duidelijk, over zijn sensorische overgevoeligheid. Beklaagt hij zich over de vele doktoren met wie hij te maken krijgt dan is dat een uiting van zijn behoefte aan houvast en zekerheid. Uit hij zijn ergernis over het lang moeten wachten dan geeft hij wellicht zijn angst weer dat hij het intussen niet redt. Dit luisteren naar de emotionele weerklank via het klankbord van wat de patiënt over zijn fysische en relationele omgeving vertelt, is tot mijn erfenis uit de fenomologie blijven behoren. Dit luisteren en verstaan verdient aan medische studenten te worden overgedragen. In de individuele patiëntenzorg levert dit extra informatie ten behoeve van diagnostiek en behandeling. Voor research levert het de nodige onderzoekswaardige hypothesen. Ook hier geldt het simpele adagium, "bezint eer ge begint", want anders wordt het onbezonnen werk.

Het spanningsveld tussen methodologische perfectie en psychologische relevantie heeft Barendregt (1982) ooit benoemd als de neurotische paradox in ons vak: als onderzoek methodologisch deugdzaam is, is het maar al te vaak niet relevant voor de klinische praktijk. en omgekeerd als het relevant was voor de praktijk was het veelal niet deugdelijk genoeg naar streng methodologische maatstaven. Na mijn opleiding als psycholoog praktiserend in de kliniek en in de ambulant geestelijke gezondheidszorg, vervolgens benoemd aan deze faculteit heb ik deze paradox beter leren onderkennen: wat toetsbaar is, is niet steeds belangrijk en wat belangrijk is, is niet steeds toetsbaar. Bij ieder onderzoek op medischpsychologisch gebied dient in deze een eigen compromis te worden gesloten. Soms overheerst daarin de klinische relevantie vanwege de toetsing van in de patiëntenzorg nijpende problematiek. Dan weer heeft de oplossing van een meer fundamenteel probleem de overhand, ook al zijn de consequenties voor de praktijk van zulk een probleemoplossing op voorhand niet voorspelbaar. In het ene geval spitst de oppositie ter promotie zich toe op de vraag wat de klinicus practicus met de onderzoeksconclusies aan moet. In het ander geval struikelen de opponenten op methodologische gronden over de betrouwbaarheid, de geldigheid en/of de generaliseerbaarheid van de conclusies.

Juist de academische afdelingen Medische Psychologie, die wat betreft de psychologic de afstand tussen faculteit der geneeskunde en academisch ziekenhuis hebben te overbruggen, 
zijn aan dit spanningsveld onderhevig. Zeker is dat het onderwijs in de Medische Psychologie is gediend met een zo goed mogelijke overbrugging van onderzoek en patiëntenzorg. Een loopbrug zoals hier bestaat tussen facultaire vakgroep en ziekenhuisafdeling faciliteert daarbij wel, maar voor optimale integratie van beide dienen soms wegversperringen opgeruimd te worden.

Tussen Eysenck's typering van de individuele patiënt als "simply the point of intersection of a number of quantitative variables" en de voor de kliniek bruikbare psychologische rapportage over een patiënt gaapt dan ook nog altijd de grote kloof van enerzijds empirischanalytisch onderzoek op groepsniveau en anderzijds de praktische toepassing van psychologische bevindingen in de kliniek.

Het lijkt er sterk op dat de probleemgeoriënteerde aanpak, die vanuit Maastricht zich snel is gaan voortplanten in het onderwijs aan andere faculteiten geneeskunde in den lande, nu ook steeds meer wordt aangegrepen in de patiëntenzorg op psychologisch, psychotherapeutisch gebied. Steeds meer wordt de hulpvraag van de patiënt richtinggevend voor het aanbod aan interventies en therapie. Het tij is aan het keren van aanpassing van de vraag aan het aanbod naar aanpassing van het aanbod aan de vraag van degene, die hulp nodig heeft.

Zorg op maat was al eerder een thema op macro- en meso-niveau van de gezondheidszorg. Toch lijkt de strijd in het spanningsveld tussen meer ziekte- versus meer persoonsgerichte hulpverlening nog lang niet gestreden. De opkomst van de term disease-management geeft wat dat betreft te denken. Afgezien van het feit dat in deze term cure en care onder management worden samengevat lijkt ziektebestrijding daarmee als een soort product op de markt te worden verhandeld. Opnieuw dreigt daarbij de ziekte centraal te worden gesteld in plaats van de persoonlijke identiteit van de zieke persoon zelf. Het gevaar van reductionisme blijft op de loer liggen ten aanzien van de patiënt in zijn gang door de echelons van de gezondheidszorg.

Dit gevaar van reductionistisch handelen in de geneeskunde kan als volgt worden uitvergroot: Wordt de patiënt door de huisarts in de eerstelijnsgezondheidszorg nog gezien als persoon in de context van zijn gezin en buurt, eenmaal op de polikliniek van het specialisme waarnaar hij verwezen is, wordt hij maar al te vaak "ontdaan" van zijn levensomgeving en veelal hooguit gezien als individu soms met partner. Bij opname in het ziekenhuis loopt hij vervolgens het risico te worden gereduceerd tot het orgaansysteem, waarin de stoornis wordt vermoed dan wel is aangetoond. Altitude-onderwijs kan bijdragen tot de alertheid op dit soort tendenzen. 


\section{INTERVENTIES}

In de medische psychologische, psychodiagnostische praktijk gaat het zowel om overeenkomsten van de patiënt met bepaalde categorieën andere patiënten als ook om die verschillen welke hem of har typeren in zijn individualiteit inclusief zijn of haar individuele problematiek. Door toepassing van de door middel van onderzoek op groepsniveau gevonden wetmatigheden worden probleemoplossingen en therapeutische interventies gezocht ter hulpverlening aan de individuele patiënt. Hoe efficiënt en pragmatisch de tendens naar protocollaire behandeling ook is, op het micro-niveau van de individuele patiëntenzorg blijft ook zorg op individuele maat aangewezen.

Aan wetenschappelijk onderzoek wordt als éen van de criteria gesteld: herhaalbaarheid. Vandaar de minitueuze beschrijving van onderzoeksopzet, kenmerken van proefpersonen en gebruikte methoden zodat in principe duplicatie van het onderzoek mogelijk is.

Hoe anders ligt dit in de behandeling van de individuele patiënt. Deze leeft in een eigen, unieke, niet te dupliceren of te herhalen levenssituatie. Met een bepaalde, hem of haar zelf veelal onbekende aanleg van begaafdheden, beperkingen en kwetsbaarheden, opgegroeid met deze ouders in dit gezin, gekomen op deze maatschappelijke positie na deze opleiding en met deze lichamelijke conditie etc., is ook de uitwerking van ziekte per persoon verschillend.

Geen ziekte is voor twee mensen gelijk, zeker niet wat betreft betekenis die ieder van hen daaraan verleent. Toch dienen de oplossingen, interventies, therapieën en adviesrichtlijnen voor somatopsychische zowel als psychomedische problemen ontwikkeld te worden vanuit gevonden overeenkomsten in effecten van clinical trials ook wat betreft medisch psychologische interventies.

Ook in geval van psychische problematiek bij lichamelijke aandoeningen dienen beslissingen over de meest aangewezen interventie of behandeling gebaseerd te zijn op de nodige diagnostiek. Afhankelijk van de hulpvraag van de patiënt of van de vraagstelling van de verwijzend arts maakt de psycholoog een keuze uit het uitgebreid arsenaal van psychodiagnostische methoden en instrumenten. De diagnostische fase beoogt de vorming en toetsing van hypothesen over het ontstaan en voortduren van de betreffende problematiek. Door middel van het aldus geprogrammeerde psychologisch onderzoek wordt inzicht verkregen in het psychisch functioneren van de patiënt in relatie tot de personen en omstandigheden, welke bij zijn problematiek een rol spelen. Uit de diagnostische onderzoeksbevindingen wordt het nodige advies aan de behandelend arts afgeleid dan wel de 
indicatiestelling gevormd voor specifieke psychologische begeleiding, behandeling of andersoorige interventies.

Het arsenaal aan interventies en behandelingen bestaat o.a. uit advies en begeleiding, crisisinterventie, kortdurende inzichtgevende therapieën en diverse gedragstherapeutische methoden. Vooral in deze laatstgenoemde sector doen zich nieuwe ontwikkelingen voor wat betreft: a.) operante conditionering ter bevordering van gewenst gedrag, b.) exposuretechnieken ter uitdoving van angst, c.) cognitief therapeutische methoden ter correctie van irrationele invaliderende gedachteninhouden.

Medische situaties, zowel onderzoeken als ingrepen, kunnen een bedreigend karakter hebben door het fysiek gevaar dat deze situaties suggeren. Vandaar de prikvrees voor injecties, conditionering op misselijkheid bij chemotherapie, angst voor ziekenhuizen, claustrofobie in dokterswachtkamers. Vaak leiden bedreigende, al of niet pijnlijke ervaringen met medische situaties tot anticipatie-angst, welke een goed verloop van onderzoek of behandeling ernstig kan bemoeilijken. Juist in zulke situaties speelt de arts-patiënt relatie een cruciale rol, niet alleen in het doorbreken van uit zulke relaties voortkomende impasses, maar ook in het ontstaan van deze angsten, vermijdingsgedragingen, afweer en verzet. Op grond van zijn onderzoek naar de perceptie van medische situaties door patiënten concludeert Van der Ploeg (1988) dat niet alleen anticipatie op medische ingrepen als stressvol worden ervaren, maar dat gebrek aan open en vrije communicatie van arts en patiënt vaak minstens evenzeer, zo niet meer stresserend wordt ervaren.

Daar waar ziekte tot stressreacties leidt, dient gebruik gemaakt te worden van de mogelijkheden om ook de negatieve, bedreigende beoordeling van de situatie door de patiënt cognitief te herstructureren door uitleg en informatie en van zijn negatieve emotionele lading te ontdoen door de patiënt zoveel mogelijk zelfcontrole te geven over wat er dient te gebeuren. Hoe meer zelfcontrole mogelijk wordt gemaakt, hoe minder bedreigend de situatie voor de patiënt wordt.

\section{HOOGTEPUNTEN}

Bij mijn gedachtenordening voor dit afscheid heb ik mij afgevraagd wat ik als hoogtepunten in de afgelopen periode heb ervaren. Stellig behoren daartoe de eerste jaren van onze faculteit. Naar ik aanneem heeft ieder die bedoelde beginjaren heeft meegemaakt deze als 
bijzonder uitdagend, inspirerend en boeiend ervaren. Mijn deelname aan de vier eerste faculteitsbesturen, respectievelijk onder voorzitterschap van Tiddens en Greep gaf aan deze uitdaging extra vorm. Ondanks de start in een aanvankelijk beperkte accommodatie moest toen de koers van de Medische Faculteit Maastricht worden bepaald, op de eerste plaats voor het onderwijs. Vernieuwde vormgeving aan de studic geneeskunde door middel van probleemgeoriënteerd onderwijs vormde immers de voornaamste reden voor de instelling van de achtste Medische Faculteit die uiteindelijk zou uitgroeien tot Universiteit Maastricht met nu 7 faculteiten en ruim 8500 studenten. De opstart daarvan vormde een onvergetelijke pionierstijd van grote onderlinge solidariteit en samenwerking van een ieder in het algemeen belang. Dit bindmiddel van het algemeen belang lijkt in deze tijd van individualisering en competitie wel eens aan kracht in te boeten.

Als hoogtij heb ik ook de 12 jaar ervaren waarin ik het voorrecht kreeg deel uit te maken van het College van Advies en Bijstand van de Gezondheidsraad. Om vanuit de medische psychologie als eerste psycholoog in dit gerenommeerde gezelschap betrokken te zijn was een bijzonder professioneel genoegen. Op basis van de stand van wetenschap werden in dit college alle rapporten en adviezen van de Gezondheidsraad aan de overheid becommentarieerd onder uitdagend voorzitterschap van Prof. Dr. C. Haex en later Dr. L. Stuyt en Dr. L. Ginjaar.

Bijzondere hoogtepunten zijn steeds promoties, uiteraard voor de gepromoveerden maar niet minder de promotor. Begeleiding van promotie-onderzoek is voor de promotor een extra aanzet om zich bezig te houden met de core business van zijn vak en tegelijk met de grenzen daarvan vanwege de bedoeling om daar zo mogelijk enige verschuiving in te brengen. Dat 4 van de 19 bij mij of mede bij mij gepromoveerden zich intussen zelf het jus promovendi verwierven schenkt extra voldoening. Met de collegae van de Bosch, Nijhuis, van den Hout en Griez gaat de vertakking verder van de academische stamboom, waarvan ik deel uitmaak via mijn al te vroeg overleden promotor Prof.dr. Ben Kouwer, die weer geënt was op Prof.dr. F. Buytendijk, die zelf de Utrechtse fysioloog Prof.dr. H. Zwaardemaker als promotor had. De vertakking van academische stambomen verloopt intussen door het AIOstelsel in versneld tempo, waardoor zij steeds meer vrucht dragen. De onderwerpen van de promotieonderzoeken, welke ik mocht begeleiden dan wel medebegeleiden, geven een indruk van de variëteit van probleemgebieden, waarmee de medische psychologie zich bezighoudt. Ondanks deze variëteit vormen zij overigens uiteraard slechts een selectie uit het gehele vakgebied. Aangezien het slecht doenlijk is al deze onderwerpen apart te noemen geef ik 
daarvan een thematisch geclusterde opsomming mede ter illustratie van de aanzet die zij hebben gevormd voor voortgezet onderzoek.

a. Revalidatie van gedragsdeviaties, van psychische functiestoornissen bij cerebraalgestoorden en van lichamelijke handicaps: resp. J. Schuerman (1977), L. Fasotti (1992) en M. Poulssen (1979).

b. Psychologische aspecten van lichamelijke ziekte (m.n. nierdialyse- en hartinfarctpatiënten: resp. J. Loos (1981) en H. van Dijl (1981).

c. Vaardigheidstherapieën: M. Beekers (1982) en B. Beckers (1986).

d. Arbeid en gezondheid: F. Nijhuis (1984), W. Lancée (1988) en N. Boumans (1990).

e. Psychopathologie (R. van den Bosch (1982), M. van den Hout en E. Griez (1985) en W. Weeda-Mannak (1984).

f. Pijnproblematiek (A. Schmidt (1986) en J. Vlaeyen (1991).

g. Diversen (i.e. Gender-identiteits-, defaecatie-, stressproblematiek, resp. R. Sohier (1983), H. van der Bruggen (1991) en H. van Berkum (1992).

Het onderwerp 'Psychologische aspecten van somatische ziekten' vond onder leiding van collega Ad Appels (1991) vruchtbaar voortgang tot in de divisie van de onderzoeksschool CARIM betreffende Psychosociale aspecten van het hartinfarct in het algemeen en vitale uitputting als risicoindicator voor het hartinfarct en de plotselinge dood in het bijzonder.

Het onderwerp Vaardigheidstherapieën resulteerde in methodieken, welke een waardevolle aanvulling vormen op het gedragstherapeutisch arsenaal van de ambulante geestelijke gezondheidszorg ten behoeve van kansarmen, die door hun deficiënties in copinggedrag in psychosociale problemen komen.

Het thema Arbeid en Gezondheid heeft zich verzelfstandigd in de onderzoeksgroep onder leiding van collega Frans Nijhuis betreffende Bedrijfsgezondheidkundige interventies inclusief arbeidspsychologische aspecten van diverse ziekenhuiswerkzaamheden.

Het thema Psychopathologie werd onder leiding van collega Van den Hout (1997) vervolgd en uitgebouwd tot de onderzoeksschool Experimentele Psychopathologie. Het onderzoek 
daarvan richt zich o.a. op op stoornissen in de verwerking van interoceptive signalen en de uitwerking daarvan op angst en pijn ook in medische situaties.

Het onderwerp Pijnproblematiek vond behalve in deze onderzoeksschool ook uitbouw in het Pijnteam/Pijnkenniscentrum van het Academisch Ziekenhuis Maastricht o.a. door medewerking van Dr. Nico Groenman.

Het stressonderzoek, in casu bij ouders van verstandelijk gehandicapten, is te zien als voorbode van de produktiviteit van de door de Stichting Wetenschappelijk Instituut Historisch Centrum voor verstandelijk gehandicapten (SWIHC) ingestelde Gouverneur Kremers leerstoel, thans bezet door collega A. van Gennep.

Als voorafspiegelingen en voorbodes van later verzelfstandigde onderzoekslijnen en vakgroepen illustreren deze promoties de opstartfunctie van de vakgroep Medische Psychologie. Uit dit overzicht blijkt hoe een capaciteitsgroep als lanceerbasis heeft te fungeren voor wetenschappelijk medewerkers zowel als voor nieuwe onderzoekslijnen, ook al betekent verzelfstandiging in deze soms verlies voor de vakgroep ten bate van winst voor de faculteit(en).

Afscheid nemen lukt het best met zo veel mogelijk finished business. Hoe meer ik afgerond kan achterlaten, hoe vrijer ik mijn otium - naar ik hoop - cum dignitate tegemoet kan zien.

Het is overigens opmerkelijk dat men in de Romeinse tijd: handeldrijven, zaken doen, kortom werken, betitelde als ontkenning van vrije tijd: negotie. In onze tijd zijn wij immers omgekeerd geneigd vrije tijd als tijd zonder werk te definiëren.

Bij het opmaken van de balans blijken mij met name de volgende zaken nog verdere ontwikkeling te behoeven:

- de academisering van de afdeling Medische Psychologie van AZM, d.w.z. de integratie van vakgroep en afdeling medische psychologie is nog (net) niet afgerond, hoewel daar de laatste jaren wel meer back-bone in kwam;

- attitude-ontwikkeling heeft nog niet die plaats in het curriculum en die aandacht van de faculteit gekregen, die dit essentiële element voor de arts - in opleiding - verdient;

- de door ons gelanceerde afstudeerrichting Geestelijke Gezondheidkunde heeft geheel ten onrechte nog steeds geen toegang tot de bij de wet BIG ingestelde opleiding en registratieregeling voor gezondheidspsychologen. Voorzover nog niet door de recente ontwikkelingen in deze achterhaald, doe ik bij deze een dringend beroep op alle betrokken adviesorganen, met name ook op het Nederlands Instituut voor Psychologen (NIP) om op inhoudelijke gronden de toelating tot deze beroepsoplei- 
ding mogelijk te maken voor deze - kwalitatief goed opgeleide en potentieel voor de individuele geestelijke gezondheidzorg waardevolle - categorie gezondheidkundigen. Met de afronding van deze kwesties en met alle overige ontwikkelingen in medisch psychologisch perspectief wens ik faculteit, vakgroep en alle overige betrokkenen van harte succes.

\section{SLOTWOORD}

Mijnheer de Rector Magnificus, dames en heren,

Tegen het einde van mijn afscheidsrede is het mij een behoefte tot uitdrukking te brengen, dat ik het als een voorrecht ervaar meer dan 23 jaar als hoogleraar aan deze universiteit en deze faculteit te hebben mogen functioneren. Al degenen, die vanaf de start van de Medische Faculteit Maastricht, de eerste jaren van opbouw, ontwikkeling en uitbouw mee hebben vormgegeven, zullen - zo ben ik vrijwel zeker - mijn overtuiging delen, dat vooral die eerste jaren een onvergetelijk boeiende periode vormden: turbulent, uitdagend, spannend door het nieuwe, de exploratie van onontgonnen gebieden zowel in onderwijs, onderzoek, patiëntenzorg en niet te vergeten het bevestigen van samenwerking met vele nieuwe partners op deze terreinen. Vooral die beginjaren heb ik ervaren als één prikkelend beroep op creativiteit en inventiviteit, door het contact met collegae, medewerkers en last but not least, met studenten. Terecht bespeurt $U$ nu de nostalgie van de scheidende functionaris, dus ga ik snel over naar het hier en nu.

Tot slot betuig ik van harte dank aan allen, die de nu af te sluiten tweede fase van mijn werkleven voor mij tot een plezierige en voldoeninggevende periode hebben gemaakt.

Allereerst ben ik het College van Bestuur en de Faculteit der Geneeskunde erkentelijk daartoe de voorwaarden te hebben gecreëerd. Waar aangewezen vond ik bij $u$ het nodige begrip.

Speciaal erkentelijk ben ik jou, Ad Appels, als meest naaste collega en sparring partner, en jou, Ton Schmidt, als werker van het eerste uur. Ook al noem ik jullie met name, mijn dank geldt evenzeer ieder persoonlijk van alle medewerkers van het eerste tot en met die van het huidige uur, zeker ook de secretaressen, van wie ik steeds zoveel steun en toewijding heb ondervonden. Voorts dank ik alle medewerkers van de AZM-afdeling Medische Psychologie 
voor de steeds prettiger samenwerking. Extra respect heb ik in deze voor jou, Peter Boon, waar jij maar al te lang het hoofdschap van de afdeling ad interim hebt vervuld. De in de naaste toekomst voorziene (ré)unie van de vakgroepen Medische Psychologie en Differentiele en Experimentele Psychologie is mijns inziens veelbelovend voor de nodige voltooiing van de zolang gewenste academisering van de Medische Psychologie. De compositie van deze toekomstmuziek is geschreven, nu dient hij nog te worden uitgevoerd door de diverse spelers, ieder op hun eigen instrument.

Het meest dankbaar ben en blijf ik mijn vrouw. Met jou naast mij. Mimi, heb ik kunnen doen, waar $\mathrm{ik}$ mij professioneel toe geroepen voelde. Weinigen weten wat $\mathrm{jij}$ allemaal weet te verzetten. Trots ben ik op je tomeloze energie en ingenomen ben ik met je toewijding. Als mijn steun en toeverlaat in al die jaren samen ben ik je onnoemelijk dankbaar uit de grond van mijn hart, dat zoveel meer voor je in zich bergt dan ik je hier zeggen zal. Samen hopen wij er nog lang getuigen van te zijn dat het $\mathrm{u}$ zo goed gaat als wij $\mathrm{u}$ dat toewensen.

De Universiteit en de Faculteit Geneeskunde wens ik een veelbelovende en daarmee uitdagende toekomst.

Ook de vakgroep en ziekenhuisafdeling Medische Psychologie wens ik een boeiende toekomst, uiteraard samen in één medisch-psychologisch perspectief. 


\section{Referenties:}

Appels, A. (Ed.) (1991). Behavioural observations in cardiovascular research. Amsterdam, Swets en Zeitlinger.

Barendrecht, J.T. (1982). De zielenmarkt. Meppel, Uitg. Boom.

Batenburg, V. (1995). De ideale arts; het beroepsbeeld van medische studenten. N.T.v. Geneeskunde, 23, 1170-1181

Beckers, B.M.C. (1986). Persoonlijke vaardigheidstherapieën voor kansarmen. Lisse, Swets \& Zeitlinger.

Beekers, R.J.M. (1982). Interpersoonlijke vaardigheidstherapieën voor kansarmen. Lisse, Swets \& Zeitlinger.

Berkum, H.W. van (1992). Stress bij ouders van een verstandelijk gehandicapped kind. Amsterdam/Lisse, Swets \& Zeitlinger.

Bierkens, P.B. (1994). Medische Psychologie: oud en nieuw. Afscheidscollege Katholieke Universiteit Nijmegen.

Bosch, R.J, van den (1982). Attentional correlates of schizofrenia and related disorders. Lisse, Swets \& Zeitlinger.

Boumans, N.P.G. (1990). Het werk van verpleegkundigen in algemene ziekenhuizen. Diss. Maastricht, Datawyse.

Bremer, J.J.C.B. (1980). The patient as an active participant in his own treatment. Strasbourg, Council of Europe.

Bremer Schulte, M., Blijham, G., Schrey, G. en Bremer, J. (1995). Empowerment through selfcare and mutual aid. Maastricht Universitaire Pers Maastricht. 
Bruggen, H. van (1991). Patiënt, privaat en privacy, Lochem. De Tijdstroom.

Dijl, H. van (1981). Psychologische kenmerken van hartinfarctpatiënten. Lisse, Swets \& Zeitlinger.

Fasotti, L. (1992). Arithmetical word problem solving after frontal lobe damage. Amsterdam/Lisse, Swets \& Zeitlinger.

Griez, E. en Hout, M.A. van den (1985). Carbon dioxyde and anxiety. Diss. Maastricht.

Hout, M.A. van den (1997). De paniekstoornis, fobieën en gegeneraliseerde angst. In: Molen, H.J. van, Perreyn, S en Hout, M.A. van den: Klinische Psychologie. Groningen, Wolters-Noordhoff

Klip, E. (1991). Klinische psychologie in de medische situatie. In: J.A.M. Winnubst e.e. (red.). De Metamorfose van de klinische psychologie. Assen/Maastricht, Van Gorcum.

Knegtmans, P.J. (1992). De Medische Faculteit Maastricht. Assen/Maastricht, Van Gorcum.

Kraaimaat, F.W. (1996). De anatomie van de medische psychologie. Rede Katholieke Universiteit Nijmegen.

Kuhn, Th. (1970). The structure of scientific Revolutions. Chicage. The University of Chicago Press.

Lancée, W.H.J. (1988). Psychologisch onderzoek inzake arbeids(on)geschiktheid. Diss. Maastricht.

Loos, J.C. (1981). Psychologische kenmerken van het leven maet de kunstnier. Lisse, Swets \& Zeitlinger.

Nijhuis, F. (1984). Beoordeling van organisatiekenmerken, Diss. Maastricht.

Ploeg, H.M. van der (1988). Stressful medical events: a survey of patient perceptions. In: S. 
Maes, C.D. Spielberger, P.B. Defares en I.G. Sarason (red.): Topics in health psychology. Chichester.

Poulssen, M.G.N. (1979). Verandering en verschuiving, Diss. Maastricht.

Scherpbier, A.J.J.A. (1997). Kwaliteit van vaardigheidsonderwijs gemeten. Maastricht, Universitaire Pers Maastricht.

Schmidt, A.J.M. (1986). Persistence behaviour of chronic low back patients. Diss. Maastricht.

Schuerman, J.A. (1977). Revalidatie van gedragsdeviaties bij cerebraal gestoorden. Diss. Maastricht.

Sohier, R. (1983). Return to Zion: Gender Identity and religion in a proscriptive society. Diss. Maastricht.

Vlaeyen, J.W.S. (1991). Chronic low back pain. Lisse, Swets \& Zeitlinger.

Weeda-Mannak, W.L. (1984). Anorexia nervosa. Diss. Maastricht.

Wintzen, A.R. (1996). "Hoe is het?" Oratie Rijksuniversiteit Leiden. 